\title{
Anesthetic Use In Status Epilepticus: A Concise Review
}

Furkan M. Yilmaz MD.

Cooper University Hospital, Department of Neurology, mdfurkanyilmaz@yahoo.com

Lauren A. Igneri PharmD

Cooper University Hospital, Department of Pharmacy, igneri-lauren@cooperhealth.edu

Yasir A. Yilmaz MD.

Ankara University School of Medicine, Department of Neurology, a.yasiryilmaz@gmail.com

Evren Burakgazi-Dalkilic MD.

Cooper University Hospital, Department of Neurology, burakgazi-dalkilic-evren@CooperHealth.edu

Cooper Rowan Medical Journal: https://rdw.rowan.edu/crjcsm

Would you like to be a reviewer? Please fill in this short form to express your interest.

\section{Recommended Citation}

Yilmaz, Furkan M. MD.; Igneri, Lauren A. PharmD; Yilmaz, Yasir A. MD.; and Burakgazi-Dalkilic, Evren MD.

(2020) "Anesthetic Use In Status Epilepticus: A Concise Review," Cooper Rowan Medical Journal: Vol. 2 :

Iss. 1 , Article 2.

DOI: 10.31986/issn.2578-3343_vol1iss2.2

Available at: https://rdw.rowan.edu/crjcsm/vol2/iss1/2

\section{(c) (i)}

This work is licensed under a Creative Commons Attribution 4.0 License.

This Concise Review and Clinical Update is brought to you for free and open access by the Rowan University Journals at Rowan Digital Works. It has been accepted for inclusion in Cooper Rowan Medical Journal by an authorized editor of Rowan Digital Works. For more information, please contact brush@rowan.edu. 
Anesthetic Use In Status Epilepticus: A Concise Review

This concise review and clinical update is available in Cooper Rowan Medical Journal: https://rdw.rowan.edu/crjcsm/ vol2/iss $1 / 2$ 


\title{
Anesthetic and Continuous Infusion Midazolam Use In
} Refractory Status Epilepticus: A Concise Review

\author{
Furkan M Yilmaz, $\mathrm{MD}^{1 *}$, Lauren A Igneri, PharmD ${ }^{2}$, Yasir A Yilmaz, $\mathrm{MD}^{3}$ \& \\ Evren Burakgazidalkilic, $\mathrm{MD}^{4}$
}

\author{
${ }^{1}$ Neurocritical Care Fellow, The Ohio State University Wexner Medical Center, Ohio, Columbus, USA \\ ${ }^{2}$ Critical Care Clinical Pharmacy Specialist, Cooper University Hospital, New Jersey, Camden, USA \\ ${ }^{3}$ Beypazari State Hospital, Neurologist, Ankara, Turkey \\ ${ }^{4}$ Epilepsy/Neurology Specialist, Cooper University Hospital, Camden, New Jersey USA \\ *Corresponding author: mdfurkanyilmaz@yahoo.com (Furkan M Yilmaz, MD)
}

\begin{abstract}
The purpose of this review is to summarize the recent literature focusing on intravenous (IV) administration of commonly used anesthetics, including midazolam, pentobarbital/ thiopental, propofol, and ketamine in the treatment of status epilepticus (SE). Anesthetics should be reserved as third-line therapy for the treatment of SE when benzodiazepines and other second-line agents fail to terminate the seizure. We have reviewed the literature related to the treatment of status epilepticus, refractory status epilepticus, super-refractory status epilepticus, anesthetics, midazolam, pentobarbital/thiopental, propofol, and ketamine. This paper focuses on the pharmacology, dosages, major side effects, and clinical use of IV anesthetics in the treatment of SE with an emphasis on the developing literature supporting the use of ketamine for this indication. Based on the available literature, we propose recommendations for third-line agent selection in the management of SE.
\end{abstract}

\section{INTRODUCTION}

Anesthetics (pentobarbital/thiopental/phenobarbital, propofol, and ketamine) and continuous infusion midazolam are widely used for seizures that do not respond to initial emergent benzodiazepines to curtail seizures and initiation of second-line antiepileptic drugs (AED). Status epilepticus (SE) is defined as 5 minute or more of continuous or intermittent (without recovery between seizures), clinical and/or electrographic seizure activity. ${ }^{1} \mathrm{SE}$ can be either convulsive SE (convulsions with rhythmic jerking movement) or non-convulsive SE (seizure activity on electroencephalography (EEG) without 
convulsions). ${ }^{1}$ If SE does not respond to intravenous (IV) benzodiazepines and a second-line AED (including IV fosphenytoin, phenytoin, valproic acid, levetiracetam, or phenobarbital), then the patient has progressed to refractory status epilepticus (RSE), which requires further treatment with anesthetics. Super-RSE occurs when RSE does not respond to continuous infusion IV anesthetics. ${ }^{2}$ Since anesthetics are used in the treatment of refractory SE after administration of benzodiazepines and second-line antiepileptics, they are commonly called third-line antiepileptics. Continuous EEG monitoring should be utilized in the diagnosis and treatment of the condition as well as the adjustment of the medications. ${ }^{3}$

SE is a time-sensitive emergency that requires immediate treatment. ${ }^{4}$ Rapid cessation of SE is necessary as it is shown in multiple studies that prolongation of SE can make the condition more resistant to treatment and complicates with neurological and systemic adverse outcomes. ${ }^{5}$ Therefore, anesthetics should be readily available in any clinical setting where SE is managed, as $40 \%$ of patients with SE do not respond to first-line drug therapy and will require additional treatment ${ }^{2}$ and $43 \%$ of patients will progress to RSE. ${ }^{6}$ IV anesthetic drugs should be used to induce a therapeutic coma as the next level of the treatment of SE. On average, cessation of SE requires three AEDs. ${ }^{7}$

Despite extensive use of anesthetics in the treatment of SE, there are not any completed, randomized-controlled studies that compare safety and efficacy between anesthetic groups. ${ }^{8}$ Prospective studies showed that after controlling for confounders, anesthetic use is associated with poor outcome [death, worse Glasgow Outcome Score (GOS) $]^{9}$, increased risk of disability, infections, and extended hospitalization in the treatment of SE. ${ }^{10}$ These findings may also reflect the medical complications of extended SE, as this group is more likely to have a therapeutic coma. ${ }^{11}$ Additionally, systematic reviews have not demonstrated superior efficacy of one anesthetic over another in the management of SE. ${ }^{12,13}$ Therefore, anesthetic selection should be based on adverse effect profile and patient-specific factors. ${ }^{14}$

This review compares the most commonly used anesthetics in the setting of RSE, including propofol, pentobarbital/thiopental, and ketamine, as well as IV continuous infusion midazolam. The use of inhaled anesthetics are typically impractical ${ }^{15}$ and outside the scope of this paper. A literature search was performed on Pubmed with abstracts or titles including keywords "status epilepticus" and "anesthetics" or “midazolam" or "propofol" or "pentobarbital” or "phenobarbital” or "thiopental" or "ketamine." Out of 321 search results, 170 articles were dated between 1985-2018, written in the English language, and deemed to be related to the treatment of RSE. 57 citations were determined to include unique data for review and discussion. The same search with keywords was done at ClinicalTrials.gov and related trials were included. 


\section{Midazolam for Refractory Status Epilepticus}

Midazolam is the single most commonly used medication to control SE. ${ }^{16}$ Gamma aminobutyric acid (GABA) secretion from the substantia nigra (SN) is a critical element in seizure control ${ }^{17}$, and midazolam is a benzodiazepine that enhances the inhibitory effect of GABA by binding post-synaptic $\mathrm{GABA}_{A}$ receptors. ${ }^{4}$ Midazolam can be administered through intramuscular, buccal, or intranasal routes which is beneficial in the pre-hospital setting when IV access may not be available. ${ }^{18}$ However, inpatient administration of the drug for SE is generally limited to IV bolus and infusion which allows for rapid onset of action and dose titration. While the half-life of midazolam is considered to be short $(3 \mathrm{~h})$, sedative effects may be prolonged due to the active metabolite $\alpha$-hydroxy-midazolam. Patients with obesity, heart failure, cirrhosis, advanced age, or renal failure, or those who have received long durations of therapy, are most likely to experience sustained sedative effects [up to 50 hour(h)] after drug discontinuation. ${ }^{19}$ In RSE, midazolam is initiated with a bolus dose of 0.05 to 0.2 milligram/kilogram $(\mathrm{mg} / \mathrm{kg})$ given at a max rate of 2-4 mg/minuteand followed by continuous IV infusion at $0.1 \mathrm{mg} / \mathrm{kg} / \mathrm{h}$. If seizures are not controlled within 15 minute or there is a breakthrough seizure, an additional IV bolus dose should be administered with a concomitant infusion titration as outlined in Table 1 in the appeddix. ${ }^{1}$. Once seizures have been controlled for 24-48 hours, the midazolam infusion can be tapered down at a rate of $1 \mathrm{mg} / \mathrm{h}$ every 12 hours $^{20}$, although more rapid titration protocols have been studied with dose reductions occurring every 4-6 hours. ${ }^{21}$ Ultimately, continuous EEG monitoring and patient response should guide titration off midazolam infusion. Patients are generally considered to have super-RSE when seizures cannot be controlled with an infusion rate of $2 \mathrm{mg} / \mathrm{kg} / \mathrm{h}$, although infusions up to $2.9 \mathrm{mg} / \mathrm{kg} / \mathrm{h}$ have been studied for RSE. Once super-RSE is established, an alternative agent should be selected.

A retrospective cohort study by Fernandez et al. demonstrated that a treatment protocol with high-dose continuous IV infusion midazolam at doses up to $2.9 \mathrm{mg} / \mathrm{kg} / \mathrm{h}$ was associated with a significant reduction in withdrawal seizure rate within 48 hours of midazolam discontinuation (15\% vs. 64\%) and discharge mortality (40\% vs. $62 \%$ ) when compared to a traditional, low-dose protocol with a maximum infusion rate of $0.4 \mathrm{mg} / \mathrm{kg} / \mathrm{h} .{ }^{21}$ Patients in the high-dose cohort were more likely to develop hypotension requiring vasopressor administration (53\%) compared to the low-dose cohort (32\%), but these rates are comparable to other IV anesthetics for RSE including propofol and pentobarbital and did not increase the risk of mortality. ${ }^{8,21,22}$ No other increased adverse events associated with high-dose infusion were noted by the authors. $^{21}$

Although there is variable reported efficacy for midazolam in RSE ranging from $25 \%{ }^{20}$ to $86 \%{ }^{23}$, midazolam appears to be the safest with less metabolic and cardiovascular side effects when compared to other anesthetics. ${ }^{2}$ In addition to hypotension, other adverse reactions include bradycardia, inotropic 
support requirements, and dyselectrolytemia. ${ }^{20}$ Tachyphylaxis may develop early, even within the first day of continuous infusion administration, and will necessitate progressive increases in dose to achieve the same effect ${ }^{18}$.

\section{Anesthetics for Refractory Status Epilepticus}

Propofol. Propofol (2,6-diisopropyl phenol) is a $\mathrm{GABA}_{A}$ receptor agonist and N-methyl-D-aspartate (NMDA) receptor antagonist used in the treatment of RSE. Due to its effects of decreasing intracranial pressure and cerebral metabolism, as well as the favorable pharmacokinetic profile, propofol has been widely utilized in neurocritical care setting ${ }^{24}$ and is the second most commonly used third-line line AED for RSE. ${ }^{16}$ Propofol is highly lipophilic and acts rapidly with an onset of action of 30 seconds. While there are no active metabolites and the half-life is generally considered short (40 minute), the terminal half-life may be up to $7 \mathrm{~h}$ and can be longer in elderly patients and those who received prolonged infusions (10 days or longer) due to the increased volume of distribution. ${ }^{19,25}$ Genetic polymorphisms of the metabolizing enzymes and receptors for propofol have been proposed to impact the variation in clinical response to therapy. However, no significant correlation between cytochrome P450 genotypes, plasma propofol concentration, and loss of consciousness have been determined. ${ }^{26}$ Age, gender, ethnicity, anxiety, the use and abuse of drugs, and other genetic factors may contribute to propofol response. ${ }^{26}$ Propofol should be initiated loading dose of 1 to $3 \mathrm{mg} / \mathrm{kg}$ given as a slow IV push followed by a continuous infusion starting at 20 microgram $(\mathrm{mcg}) / \mathrm{kg} /$ minute. 1 to $2 \mathrm{mg} / \mathrm{kg}$ serial boluses may be repeated every 3-5 minute until seizures on EEG are suppressed. ${ }^{6}$ For breakthrough SE, increase rate by 5 to $10 \mathrm{mcg} / \mathrm{kg} /$ minute every 5 minute or administer a $1 \mathrm{mg} / \mathrm{kg}$ bolus. Continuous infusion rates required to maintain burst suppression vary widely, ranging from 30 to $200 \mathrm{mcg} / \mathrm{kg} /$ minute. ${ }^{1}$ It has been reported that nearly half of patients receiving propofol for RSE develop breakthrough seizures during the weaning phase. ${ }^{22}$ Patients should be monitored with continuous EEG while tapering off propofol. Tapering schedules of 20 percent every 3 hours have been proposed ${ }^{6}$, as described in Table 1.

Despite the vast clinical experience with propofol since its FDA approval as a sedative in the late $1980 \mathrm{~s},{ }^{25}$ efficacy data in RSE is limited. ${ }^{24} \mathrm{~A}$ recent, comparative study showed equal efficacy of propofol and midazolam in attaining seizure control in a small group of patients with RSE $(n=23) .{ }^{20}$ There was a significant reduction in hospital length of stay with propofol compared to midazolam (11 vs. 20.5 days, $\mathrm{p}=0.02)$, but also a non-statistically significant increase in mortality $(72.7 \%$ vs. $58.3 \%, \mathrm{p}=0.6){ }^{20}$

Loading doses may precipitate hypotension, and caution should be utilized in patients with hemodynamic instability. Use caution when administering high doses $(5 \mathrm{mg} / \mathrm{kg} / \mathrm{h})$ for extended periods of time (i.e., 
greater than $48 \mathrm{~h}$ ), ${ }^{27}$ as this increases the risk of propofol-related infusion syndrome (PRIS). PRIS is a rare but significant complication of mitochondrial toxicity ${ }^{27}$ manifested by metabolic acidosis, rhabdomyolysis, hyperkalemia, hepatomegaly, renal failure, hyperlipidemia, arrhythmias, and rapidly progressive heart failure. ${ }^{27,28}$ Monitoring for bicarbonate, creatine kinase, potassium, liver function tests, urea/creatinine, and triglyceride levels are reasonable for long term administration of propofol. The risk for PRIS is higher in the pediatric population. ${ }^{29}$

Pentobarbital/Thiopental and Phenobarbital. Barbiturates are $\mathrm{GABA}_{A}$ receptor agonists that exert sedative, hypnotic, and anticonvulsant effects through the depression of the sensory cortex and motor activity. ${ }^{19}$ Since thiopental is no longer available in the United States, pentobarbital is the gold standard for reducing cerebral metabolism and induction of barbiturate coma in RSE that is non-responsive to midazolam or propofol. Since pentobarbital reduces intracranial pressure, it is the preferred agent for SE in the setting of traumatic brain injury and large ischemic strokes. ${ }^{30}$ While phenobarbital is also a barbiturate, its role is primarily for termination of early phase seizures that have not yet progressed to SE. ${ }^{2}$ However, there is more recent interest in its use for focal RSE and should be considered during the initial or second therapy phases (15-20 mg/kg IV push), especially when there is impairment of consciousness due to ongoing focal seizures. ${ }^{24,31}$

Both thiopental and pentobarbital are highly lipophilic, contributing to short onsets of action of 30 seconds and 3-5 minute, respectively. Although they exhibit zero-order kinetics and are hepatically metabolized to mostly inactive metabolites, there is the potential for prolonged durations of action (half-life up to $50 \mathrm{~h}$ ) due to extensive distribution in the body with deposition in the fatty tissue. ${ }^{19}$

Pentobarbital is initiated with a 5 to $15 \mathrm{mg} / \mathrm{kg}$ loading dose administered at a rate of less than $50 \mathrm{mg} /$ minute, followed by continuous infusion 0.5 to $5 \mathrm{mg} / \mathrm{kg} / \mathrm{h}$. For breakthrough SE, $5 \mathrm{mg} / \mathrm{kg}$ IV bolus can be administered, with infusion rate increases of 0.5 to $1 \mathrm{mg} / \mathrm{kg} / \mathrm{h}$ every $12 \mathrm{~h} .{ }^{1}$ Once a $24-48 \mathrm{~h}$ seizure-free interval is achieved, the infusion can be tapered off by 20 percent every 3 hours. Thiopental dosing is described in Table 1. In general, therapeutic drug monitoring is not indicated for pentobarbital or thiopental dose adjustments.

The systematic review by Claassen et al. compared the efficacy and safety of midazolam, propofol, and pentobarbital in RSE. While the phenobarbital group had a shorter median duration of RSE (13 h) compared to the midazolam group (30 h), significantly less treatment failure, breakthrough seizures, and need to change to an alternative continuous infusion AED, there was a significantly higher rate of hypotension requiring vasopressor therapy.22

Barbiturates are potent AEDs that can quickly stop seizures but at the expense of high risk for adverse 
events, including hypotension requiring vasoactive drugs to control blood pressure, prolonged mechanical ventilation, and inadequate temperature regulation. ${ }^{6,19,32}$ Although anesthetic use itself in SE increases infection risk, the risk is the highest among patients utilizing barbiturate therapy. ${ }^{13,33}$ With prolonged mechanical ventilation, there is also an increased risk for ventilator-associated pneumonia. ${ }^{6}$ One cohort study showed a high incidence of urinary tract infection (13\%), deep venous thrombosis (10\%), and ileus (10\%) in patients who received continuous infusion pentobarbital. ${ }^{34}$ Transient propylene glycol intoxication was also described. ${ }^{34}$. Drug reaction with eosinophilia and systemic symptom (DRESS) is a serious, life-threatening, but rare adverse effect that has been described with pentobarbital. There is at least one report of successful desensitization to phenobarbital maintenance therapy. ${ }^{35}$

Ketamine. It is shown in animal studies that as GABA receptors decrease during SE, excitatory $\mathrm{N}$-methyl-d-aspartate (NMDA) receptors increase. ${ }^{36}$ Ketamine is primarily a noncompetitive NMDA receptor antagonist, which has been utilized as an add-on therapy in RSE when patients fail to respond to other third-line agents. ${ }^{16,18,37}$ It may also be useful in substance abuse-related RSE. ${ }^{38}$ Ketamine interacts with several other receptors, including cholinergic (bronchodilatation, muscle relaxant), opioid (analgesia), glutamate (sedation, antihyperalgesic, anticonvulsant, neuroprotection), GABA (inhibition of neurotransmission), catecholamine (stimulation of cardiovascular function) and adenosine (immunomodulation). ${ }^{39}$ The molecule is extensively distributed in the body due to the large volume of distribution due to high lipid and water solubility. ${ }^{40}$ It has a rapid onset of action (30 seconds) and is converted to the active metabolite norketamine by the cytochrome P3A $4{ }^{18}$ which accounts for a terminal beta half-life of 2-3 h.

Although ketamine is a standard medication for anesthesia induction, there is no definitive protocol for its use in SE. ${ }^{41}$ Initial bolus doses of 1-2 $\mathrm{mg} / \mathrm{kg}$ IV push given every 3-5 minute until there is the cessation of seizure are recommended, followed by the initiation of IV continuous infusion. Significant variations in dosing have been described with most infusions ranging from 0.0075 to $10.5 \mathrm{mg} / \mathrm{kg} / \mathrm{h}$. ${ }^{41}$ However, a more recent review described typical ketamine dosing for RSE as $1-5 \mathrm{mg} / \mathrm{kg}$ IV push, ${ }^{42}$, which is similar to anesthesia induction doses, followed by continuous infusions of $0.07-15 \mathrm{mg} / \mathrm{kg} / \mathrm{h} .{ }^{18,42}$ Ketamine can be utilized in combination with another anesthetic and has been shown to have synergistic effects with benzodiazepines and propofol. ${ }^{18,43,44}$ Duration of ketamine infusion has been described ranging from $6 \mathrm{~h}$ to 29 days. $^{40}$

Regardless of the SE type, convulsive vs. non-convulsive, ketamine has been demonstrated to be twice as effective if administered early in RSE ( 3 days) compared to longer duration RSE (26.5 days). ${ }^{40}$ Despite this, its typical usage is often delayed as long as 3-9 days after seizure onset. ${ }^{45}$ An additional area of 
interest is with early ketamine administration, as this has been shown to avoid endotracheal intubation in several cases. ${ }^{40}$ Given its efficacy and safety profile, as well as the potential to reduce the need for intubation, ketamine may be considered as the first anesthetic choice for specific situations and in the out of hospital setting. ${ }^{40}$ This may be an important area for future research because intubation is a negative prognostic factor for SE. ${ }^{46}$

Available literature supporting the use of ketamine in RSE is primarily limited to observational and retrospective studies. ${ }^{40} \mathrm{~A}$ recent systematic review demonstrated excellent outcomes in SE management, with $75 \%$ of studies reporting moderate or complete seizure control in adult patients. ${ }^{41}$ There is developing interest in using ketamine due to the potential neuroprotective effects through NMDA receptor blocking, ${ }^{47}$, anti-inflammatory properties, optimization of peripheral circulation, and balancing transport and consumption of oxygen. ${ }^{39}$ There are two ongoing clinical trials of ketamine in RSE which should provide more robust data to support its use for this indication: Ketamine in Refractory Convulsive Status Epilepticus (KETASER01), ClinicalTrials.gov Identifier: NCT02431663; and Efficacy of Ketamine Infusion Compared With Traditional Anti-epileptic Agents in Refractory Status Epilepticus, ClinicalTrials.gov Identifier: NCT03115489. Interestingly, neurointensivists have more readily adopted the use of ketamine for RSE than the other physician groups. ${ }^{48}$ An area for further research would be with concomitant use of IV and enteral ketamine as case reports in RSE have shown a reduction in seizure recurrence and shortened the duration of stay in the ICU. ${ }^{49}$ Additionally, ketamine may have a niche in the setting of SE due to encephalitis due to its potent anti-inflammatory effect. ${ }^{50}$

Since ketamine is mostly used for short intervals for anesthesia induction, there is not much information on complications related to long term or high dose administration. ${ }^{41}$ Ketamine induces a positive, sympathetic response. Use is cautioned in patients with coronary artery disease and/or cardiomyopathy as it may induce hypertension ${ }^{40,51}$ tachyarrhythmias, including atrial fibrillation ${ }^{51}$, even cardiac arrest. ${ }^{52}$ Patients with subarachnoid hemorrhage (SAH) who receive ketamine have enhanced sympathomimetic effects and may develop life-threatening arrhythmias and cardiac arrest. Additionally, ketamine has been shown to cause hypotension as some large clinical series have demonstrated the need for increased vasopressor requirements when compared to other anesthetics ${ }^{40,51-53}$. Rarely, severe metabolic acidosis has been reported with doses of $4-4.5 \mathrm{mg} / \mathrm{kg} / \mathrm{hr}$ in combination with midazolam infusion. ${ }^{41}$

Additionally, encephalopathy, confusion, agitation, or psychosis can be seen even after discontinuation of ketamine. ${ }^{18,51}$ Cerebellar atrophy has been reported with ketamine use. ${ }^{54}$ Increases in oral and bronchial secretions can be prevented by administering anticholinergics. ${ }^{51}$ 


\section{DISCUSSION}

SE should preferably be managed or co-managed by a specialist since optimizing treatment will decrease mortality and treatment complications. Induction of coma with anesthetics should be promptly initiated in an appropriate clinical setting as the cessation of SE is compatible with a decrease in overall morbidity, pharmacoresistance, neuronal injury. ${ }^{2}$ When initial and subsequent treatments are delayed, resistance to AEDs increases through cellular mechanisms. ${ }^{4}$ Midazolam and propofol are usually used as initial anesthetics, while pentobarbital is often reserved for RSE unresponsive to these drugs. ${ }^{5}$ Ketamine may be preferable as adjunctive therapy in the later stages of RSE.

An initial loading dose of anesthetics should be administered, followed by continuous IV infusion. If SE does not subside, another bolus dose of the same anesthetic can be administered. If the seizures are recurring greater than 3 times within 15 minutes or do not stop within 15 minutes, the dosages should be increased to the next level. ${ }^{20}$ When seizures are not controlled at the maximum anesthetic infusion rate, RSE is considered to be super RSE, and another anesthetic should be added. ${ }^{20}$

Dosing of anesthetics should be titrated to the cessation of electrographic seizures or burst suppression with a goal inter-burst interval of 10 seconds ${ }^{55}$ EEG recordings should be sustained for $24-48 \mathrm{~h}$ before a trial of withdrawal of anesthetics. ${ }^{1} \mathrm{New}$ data also suggest that "the amount of epileptic activity in the burst" is also predictive of the success of the weaning of anesthetics. ${ }^{56}$ However, ketamine may not fit these typical EEG patterns. Diffuse slowing and diffuse beta activity patterns can also be targeted to achieve along with the burst-suppression. ${ }^{40}$ During this transition off of continuous IV infusion anesthetic, continuous EEG is essential to monitor. If continuous EEG is not available at a facility, the patient may need to be transferred to a higher level of care so that anesthetic can be safely titrated. ${ }^{1}$ Although dose adjustment, according to electrographic seizure activity, is recommended to achieve the treatment goal, this may be associated with more treatment-related complications. ${ }^{18}$

Management of withdrawing anesthetics is a delicate matter, as complications may arise during titration. Anesthetics are adjunctive therapies and must be given with second-line AEDs, which are throughout RSE and post-RSE treatment. Non-sedating AEDs should be utilized during anesthetic withdrawal episodes with careful monitoring and management. Some brief breakthrough seizures may occur during anesthetic withdrawal, but rather than increasing the anesthetic dose, ${ }^{3}$ an extra bolus dose can be given to terminate the seizure ${ }^{57}$ However, if short or brief seizures progress to SE, anesthetic tapering should be stopped and increased to the prior, effective dose. Another 24-48 h period of electrographic stability should be achieved before attempting an anesthetic withdrawal. ${ }^{20}$ If the patient is not seizure-free during these withdrawal trials, the subsequent cycle will need to be extended to greater than 48 hours. ${ }^{18}$ If tapering of the anesthetic fails more than four times, this is considered the failure of the anesthetic drug, and an alternative agent 
should be trialed..$^{20}$

\section{CONCLUSION}

The use of anesthetics is a mainstay in the treatment of RSE since they provide rapid clinical response and seizure control. The availability of continuous EEG monitoring will provide guidance to titrate anesthetics and decide when to taper anesthetics safely. Although anesthetics have been shown to terminate seizures effectively, there is an increased risk of prolonged intensive care unit stay, ventilator treatment, and complications related to the anesthetics themselves.

\section{REFERENCES}

1. Brophy G M. Guidelines for the evaluation and management of status epilepticus. Neurocrit Care. 2012;17(1):3-23.

2. Trinka Eugen, Kälviäinen Reetta. 25 years of advances in the definition, classification and treatment of status epilepticus. Seizure. 2017;44:65-73.

3. Rai Samhitha, Drislane Frank W.. Treatment of Refractory and Super-refractory Status Epilepticus. 2018.

4. Fernández Iván Sánchez, Goodkin Howard P., Scott Rod C.. Pathophysiology of convulsive status epilepticus. Seizure. 2019;68:16-21.

5. Betjemann John P, Lowenstein Daniel H. Status epilepticus in adults. 2015.

6. Legriel Stephane, Oddo Mauro, Brophy Gretchen M.. What's new in refractory status epilepticus?. 2017.

7. Cook A M. Practice variations in the management of status epilepticus. Neurocrit Care. 2012;17(1):24-30.

8. Rossetti A O. A randomized trial for the treatment of refractory status epilepticus. Neurocrit Care. 2011;14(1):4-10. 
9. Sutter R. Anesthetics and outcome in status epilepticus: a matched two-center cohort study. CNS Drugs. 2017;31(1):65-74.

10. Marchi N A. Status epilepticus: impact of therapeutic coma on outcome. Critical Care Medicine. 2015;43(5):1003-1009.

11. Bauerschmidt Andrew, Martin Andrew, Claassen Jan. Advancements in the critical care management of status epilepticus. Current Opinion in Critical Care. 2017;23(2):122-127.

12. Holtkamp Martin. Pharmacotherapy for Refractory and Super-Refractory Status Epilepticus in Adults. Drugs. 2018;78(3):307-326.

13. Shorvon S., Ferlisi M.. The outcome of therapies in refractory and super-refractory convulsive status epilepticus and recommendations for therapy. Brain. 2012;135(8):2314-2328.

14. Wiss Adam L., Samarin Michael, Marler Jacob, Jones G. Morgan. Continuous Infusion Antiepileptic Medications for Refractory Status Epilepticus. 2017.

15. Smith M. Anesthestic agents and status epilepticus. Epilepsia. 2011;52(8):42-46.

16. Ferlisi M. Preliminary results of the global audit of treatment of refractory status epilepticus. Epilepsy \& Behavior. 2015;49:318-324.

17. Wasterlain Claude G., Fujikawa Denson G., Penix LaRoy, Sankar Raman.Pathophysiological Mechanisms of Brain Damage from Status Epilepticus. Epilepsia. 1993;34(s1):S37-S53.

18. Zaccara G. Challenges in the treatment of convulsive status epilepticus. Seizure.2017;47:17-24.

19. Trinka E. Pharmacologic treatment of status epilepticus. Expert Opin Pharmacother. 2016;17(4):513-547.

20. Masapu Dheeraj, Krishna K. N. Gopala, Sanjib Sinha, et al. A comparative study of midazolam and target-controlled propofol infusion in the treatment of refractory status epilepticus. Indian Journal of Critical Care Medicine. 2018;22(6):441-448.

21. Fernandez A. High-dose midazolam infusion for refractory status epilepticus. Neurology. 2014;82(4):359-365.

22. Claassen J. Treatment of Refractory Status Epilepticus with Pentobarbital, Propofol, or Midazolam: A Systematic Review. Epilepsia. 2002;43(2):146-153. 
23. Singhi Sunit, Murthy Aruna, Singhi Pratibha, Jayashree M.. Continuous Midazolam Versus Diazepam Infusion for Refractory Convulsive Status Epilepticus. Journal of Child Neurology. 2002;17(2):106-110.

24. Hocker S. Treatment of Refractory and Super-Refractory Status Epilepticus. In: Drislane F.W.,Mbbs P.W. Kaplan, eds. Status Epilepticus: A Clinical Perspective, :201-214, Springer International Publishing; 2018.

25. Walsh C T. Propofol: Milk of Amnesia. Cell. 2018;175(1):10-13.

26. Khan M S. Pharmacogenetics, plasma concentrations, clinical signs and EEG duringpropofol treatment. Basic Clin Pharmacol Toxicol. 2014;115(6):565-70.

27. Iyer Vivek N., Hoel Rebecca, Rabinstein Alejandro A.. Propofol infusion syndrome in patients with refractory status epilepticus: An 11-year clinical experience*. Critical Care Medicine. 2009;37(12):3024-3030.

28. López N. Propofol Infusion Syndrome in a refractory epileptic status case.. Current Perspectives. 2018;89:384-390.

29. Fung E L, Fung B B. Review and update of the Hong Kong Epilepsy Guideline on status epilepticus. Hong Kong Med J. 2017;23(1):67-73.

30. Turtz A R, Goldman H W. Chapter 67 - Head Injury. In: Parrillo J.E., Dellinger R.P., eds. Critical Care Medicine, :1385-1422; 2008.

31. Glauser T, others . Evidence-Based Guideline: Treatment of Convulsive Status Epilepticus in Children and Adults. 2016.

32. Herman S. CHAPTER 5 - Acute Seizures and Status Epilepticus. In: :81-124, Academic Press; 2006.

33. Sutter R. Anesthetic drugs in status epilepticus: Risk or rescue?A 6-year cohort study.Neurology. 2014;82(8):656-664.

34. Pugin D. Is pentobarbital safe and efficacious in the treatment of super-refractory status epilepticus: a cohort study. Critical Care. 2014;18(3):103-103.

35. Witcher Robert H., Ramirez Michelle M.. Successful Phenobarbital Desensitization After DRESS Reaction in the Management of Refractory Status Epilepticus. Journal of Pharmacy Practice. 2019;32(2):228-230. 
36. Naylor D E. Rapid surface accumulation of NMDA receptors increases glutamatergic excitation during status epilepticus. Neurobiology of Disease. 2013;54:225-238.

37. Borris Douglas J, Bertram Edward H, Kapur Jaideep. Ketamine controls prolonged status epilepticus. Epilepsy Research. 2000;42(2-3):117-122.

38. Mutkule Dnyaneshwar P., Rao S., Chaudhuri Jaydip, Rajasri Kunche. Successful use of ketamine for burst suppression in super refractory status epilepticus following substance abuse. Indian Journal of Critical Care Medicine. 2018;22(1):49-50.

39. Loix S, Kock M De, Henin P J A A B. The anti-inflammatory effects of ketamine: state of the art. Acta anaesthesiologica Belgica. 2011;62(1):47-58.

40. Rosati Anna, Masi Salvatore De, Guerrini Renzo. Ketamine for Refractory Status Epilepticus: A Systematic Review. CNS Drugs. 2018;32(11):997-1009.

41. Golub D. Potential consequences of high-dose infusion of ketamine for refractory status epilepticus: case reports and systematic literature review. Anaesth Intensive Care. 2018;46(5):516-528.

42. Hofler J, Trinka E. Intravenous ketamine in status epilepticus. Epilepsia. 2018;59(2):198-206.

43. Martin Brandon S., Kapur Jaideep. A combination of ketamine and diazepam synergistically controls refractory status epilepticus induced by cholinergic stimulation. Epilepsia. 2008;49(2):248-255.

44. Niquet J. Midazolam-ketamine dual therapy stops cholinergic status epilepticus and reduces Morris water maze deficits. Epilepsia. 2016;57(9):1406-1421.

45. Dorandeu Frederic. Ketamine for the treatment of (super) refractory status epilepticus? Not quite yet. Expert Review of Neurotherapeutics. 2017;17(5):419-421.

46. Schmutzhard Erich, Pfausler Bettina. Complications of the management of status epilepticus in the intensive care unit. Epilepsia. 2011;52:39-41.

47. Cunha A O. Neuroprotective effects of diazepam, carbamazepine, phenytoin and ketamine after pilocarpine-induced status epilepticus. Basic Clin Pharmacol Toxicol. 2009;104(6):470-477.

48. Yeary Julianne, Garavaglia Jeffrey, McKnight Richard, Smith Matthew. Change in Management of Status Epilepticus With the Addition of Neurointensivist-Led Neurocritical Care Team at a Rural Academic Medical Center. Hospital Pharmacy. 2018;53(5):303-307. 
49. Pizzi M A. Transition from intravenous to enteral ketamine for treatment of nonconvulsive status epilepticus. J Intensive Care. 2017;5:54-54.

50. Caputo D. Febrile infection-related epilepsy syndrome (FIRES) with super-refractory status epilepticus revealing autoimmune encephalitis due to GABAAR antibodies. Eur J Paediatr Neurol. 2018;22(1):182-185.

51. Gaspard N. Intravenous ketamine for the treatment of refractory status epilepticus: a retrospective multicenter study. Epilepsia. 2013;54(8):1498-503.

52. Koffman L. Ketamine infusion for refractory status epilepticus: A case report of cardiac arrest. JClin Neurosci. 2018;47:149-151.

53. Sabharwal V. Propofol-ketamine combination therapy for effective control of super-refractory status epilepticus. Epilepsy Behav. 2015;52:264-270.

54. Ubogu Eroboghene E., Sagar Stephen M., Lerner Alan J., Maddux Brian N., Suarez José I., Werz Mary Ann. Ketamine for refractory status epilepticus: a case of possible ketamine-induced neurotoxicity. Epilepsy \& Behavior. 2003;4(1):70-75.

55. Rossetti Andrea O, Lowenstein Daniel H. Management of refractory status epilepticus in adults: still more questions than answers. 2011.

56. Johnson E L, Martinez N C, C E K J N. EEG Characteristics of Successful Burst Suppression for Refractory Status Epilepticus. Neurocrit Care. 2016;25(3):407-414.

57. Grover Eric H., Nazzal Yara, Hirsch Lawrence J.. Treatment of Convulsive Status Epilepticus. Current Treatment Options in Neurology. 2016;18(3):11-11. 


\section{APPENDIX}

Table 1. Pharmacologic comparison of continuous infusion midazolam and anesthetic agents for status epilepticus

\begin{tabular}{|c|c|c|c|c|c|}
\hline & $\begin{array}{l}\text { Mechanism of } \\
\text { action }\end{array}$ & Pharmacokinetics & Dosing & Major adverse events & Clinical considerations \\
\hline $\begin{array}{l}\text { Midazolam } \\
{[19,1,21,46]}\end{array}$ & $\begin{array}{l}\text { Enhances the } \\
\text { inhibitory effect of } \\
\text { GABA by binding } \\
\text { post-synaptic } \\
\text { GABAA receptors }_{\text {resulting in }} \\
\text { increased chloride } \\
\text { channel opening } \\
\text { and neuronal } \\
\text { hyperpolarization }\end{array}$ & $\begin{array}{l}\text { Onset: } 3-5 \text { minute } \\
\text { Vd: } 1-3 \mathrm{~L} / \mathrm{kg} \\
\text { Metabolism: } \\
\text { Hepatic, CYP3A4 } \\
\text { to active metabolite } \\
\alpha \text {-hydroxy- } \\
\text { midazolam } \\
\text { Half-life: } 3 \mathrm{~h} \text { (range } \\
1.8-6.4 \mathrm{~h} \text { ), up to 20- } \\
50 \mathrm{~h} \text { with prolonged } \\
\text { continuous } \\
\text { infusions (days- } \\
\text { weeks of therapy) } \\
\text { Elimination: Renal, } \\
\text { primarily as } \\
\text { conjugated } \\
\text { hydroxylated } \\
\text { metabolites }\end{array}$ & $\begin{array}{l}\text { LD: } 0.05 \text { to } \\
0.2 \mathrm{mg} / \mathrm{kg} \\
\text { given at a max } \\
\text { rate } 2-4 \mathrm{mg} / \\
\text { minute } \\
\text { Infusion rate: } \\
0.1 \mathrm{mg} / \mathrm{kg} / \mathrm{h} \\
\text { Titrate by: } \\
0.05-0.1 \\
\mathrm{mg} / \mathrm{kg} / \mathrm{h} \text { every } \\
3-4 \mathrm{~h}, \mathrm{max} \\
\text { infusion rate } \\
2.9 \mathrm{mg} / \mathrm{kg} / \mathrm{h} \\
\text { Breakthrough } \\
\text { seizures: } 0.1 \\
\text { to } 0.2 \mathrm{mg} / \mathrm{kg} \\
\text { with } \\
\text { concomitant } \\
\text { infusion rate } \\
\text { increase } \\
\text { Taper: } 1 \mathrm{mg} / \mathrm{h} \\
\text { every } 4-12 \\
\text { hours, cEEG } \\
\text { monitoring } \\
\text { recommended }\end{array}$ & $\begin{array}{l}\text { Hypotension } \\
\text { requiring vasopressor } \\
\text { support } \\
\text { Bradycardia requiring } \\
\text { inotropic support } \\
\text { Respiratory } \\
\text { depression } \\
\text { Tachyphylaxis } \\
\text { Electrolyte } \\
\text { imbalances }\end{array}$ & $\begin{array}{l}\text { High-dose infusion rates up to } \\
2.9 \mathrm{mg} / \mathrm{kg} / \mathrm{h} \text { may be preferred to } \\
\text { traditional, low-dose infusion } \\
\text { rates of } 0.4 \mathrm{mg} / \mathrm{kg} / \mathrm{h} \text { due to } \\
\text { significant reduction in } \\
\text { withdrawal seizure rate and } \\
\text { discharge mortality } \\
\text { Active metabolite may result in } \\
\text { prolonged sedative effects } \\
\text { especially in patients with } \\
\text { obesity, heart failure, cirrhosis, } \\
\text { advanced age, renal failure, or } \\
\text { those who have received long } \\
\text { durations of therapy }\end{array}$ \\
\hline
\end{tabular}




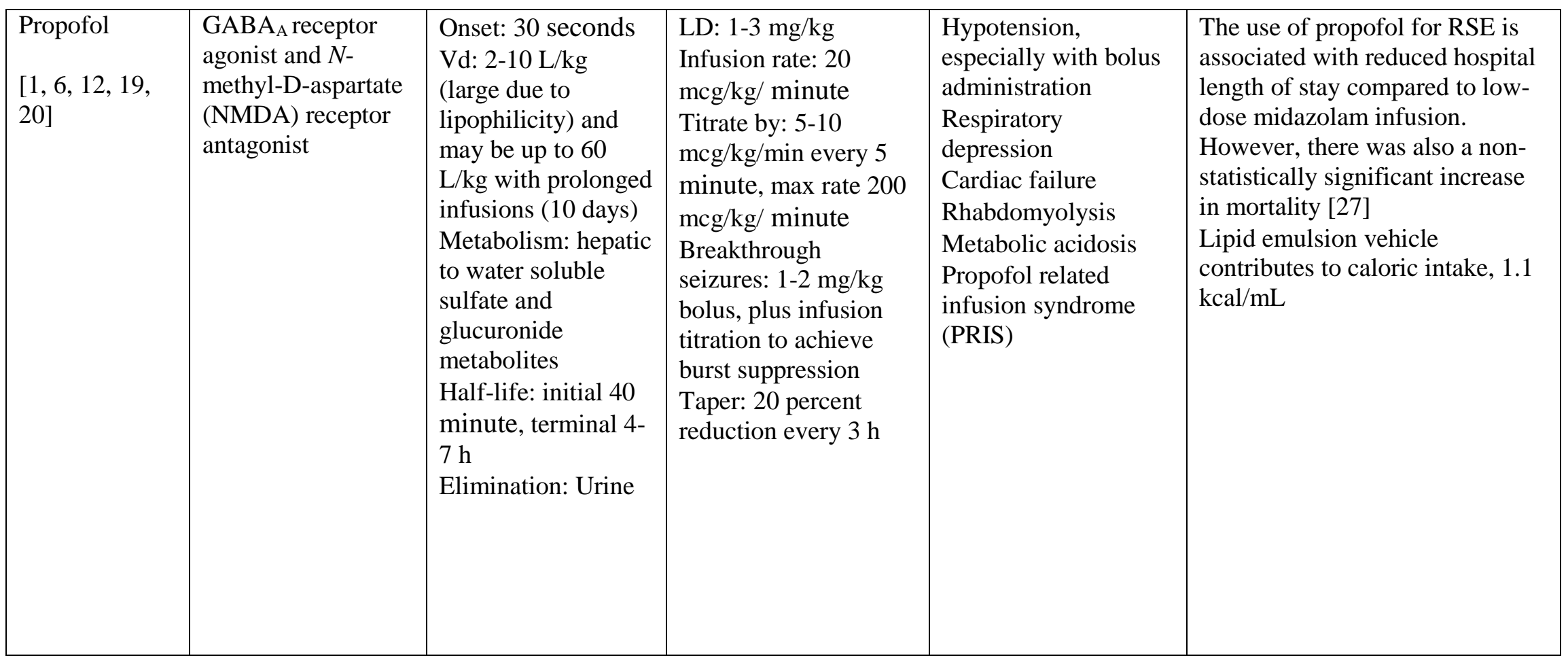




\begin{tabular}{|c|c|c|c|c|c|}
\hline $\begin{array}{l}\text { Pentobarbital } \\
{[6,12,1,19 \text {, }} \\
22,31]\end{array}$ & \multirow[t]{2}{*}{$\begin{array}{l}\text { Barbiturates are } \\
\text { acting as GABA } \\
\text { receptor agonist } \\
\text { with sedative, } \\
\text { hypnotic, and } \\
\text { anticonvulsant } \\
\text { properties through } \\
\text { the sensory cortex } \\
\text { and motor activity } \\
\text { depression. Produce } \\
\text { respiratory } \\
\text { depression, reduces } \\
\text { brain metabolism, } \\
\text { and cerebral blood } \\
\text { flow, which } \\
\text { decreases } \\
\text { intracranial } \\
\text { pressure. }\end{array}$} & $\begin{array}{l}\text { Onset: } 3-5 \text { minute } \\
\text { Vd: } 1 \mathrm{~L} / \mathrm{kg} \\
\text { Metabolism: hepatic } \\
\text { hydroxylation and } \\
\text { glucuronidation to } \\
\text { inactive metabolites } \\
\text { Half-life: } 22 \mathrm{~h} \\
\text { (range } 15-50 \mathrm{~h} \text { ) } \\
\text { Elimination: Urine }\end{array}$ & $\begin{array}{l}\mathrm{LD}: 5-15 \mathrm{mg} / \mathrm{kg} \text {, may } \\
\text { give additional } 5-10 \\
\mathrm{mg} / \mathrm{kg} \text {; administer at } \\
\text { rates } \leq 50 \mathrm{mg} / \text { minute } \\
\text { Infusion rate: } 0.5-5 \\
\mathrm{mg} / \mathrm{kg} / \mathrm{h} \\
\text { Titrate by: } 0.5-1 \\
\mathrm{mg} / \mathrm{kg} / \mathrm{h} \text { every } 12 \mathrm{~h} \\
\text { Breakthrough } \\
\text { seizures: } 5 \mathrm{mg} / \mathrm{kg} \\
\text { bolus } \\
\text { Taper: } 20 \text { percent } \\
\text { reduction every } 3 \mathrm{~h}\end{array}$ & \multirow[t]{2}{*}{$\begin{array}{l}\text { Hypotension } \\
\text { requiring vasopressor } \\
\text { support } \\
\text { Respiratory } \\
\text { depression } \\
\text { Cardiac depression } \\
\text { Ileus } \\
\text { Complete loss of } \\
\text { neurological function } \\
\text { Immunosuppression } \\
\text { Respiratory } \\
\text { depression } \\
\text { Cardiac depression }\end{array}$} & $\begin{array}{l}\text { Phenobarbital is associated with } \\
\text { a shorter median duration of } \\
\text { RSE, less treatment failure, } \\
\text { breakthrough seizures, and a } \\
\text { need to change to alternative } \\
\text { AED compared to midazolam } \\
\text { infusion. However, this may be } \\
\text { outweighed by an increased risk } \\
\text { of adverse effects. } \\
\text { Efficacy may be outweighed by } \\
\text { increased adverse reactions/side } \\
\text { effects } \\
\text { Contains propylene glycol, } \\
\text { monitor osmolar gap for } \\
\text { propylene glycol toxicity }\end{array}$ \\
\hline Thiopental & & $\begin{array}{l}\text { Onset: } 30-40 \\
\text { seconds } \\
\text { Vd: } 1.7-2.5 \mathrm{~L} / \mathrm{kg} \\
\text { Metabolism: hepatic } \\
\text { oxidation to inactive } \\
\text { metabolites, } 3-5 \% \\
\text { desulfurated to } \\
\text { pentobarbital } \\
\text { Half-life: } 3-8 \mathrm{~h} \text {, up } \\
\text { to } 10-12 \mathrm{~h} \text { with } \\
\text { prolonged } \\
\text { administration } \\
\text { Elimination: Urine }\end{array}$ & $\begin{array}{l}\mathrm{LD}: 5 \mathrm{mg} / \mathrm{kg} \text {, may } \\
\text { give additional } 1-2 \\
\mathrm{mg} / \mathrm{kg} \text { to achieve burst } \\
\text { suppression } \\
\text { Infusion rate: } 0.5-5 \\
\mathrm{mg} / \mathrm{kg} / \mathrm{h} \\
\text { Titrate by: } 0.5-1 \\
\mathrm{mg} / \mathrm{kg} / \mathrm{h} \text { every } 12 \mathrm{~h} \\
\text { Breakthrough } \\
\text { seizures: } 5 \mathrm{mg} / \mathrm{kg} \\
\text { bolus } \\
\text { Taper: None, } \\
\text { discontinue infusion }\end{array}$ & & \\
\hline
\end{tabular}




\begin{tabular}{|c|c|c|c|c|c|}
\hline $\begin{array}{l}\text { Ketamine } \\
{[13,18,40,39 \text {, }} \\
42]\end{array}$ & $\begin{array}{l}\text { Phencyclidine } \\
\text { derivative that } \\
\text { primarily acts as an } \\
N \text {-methyl-D- } \\
\text { aspartate (NMDA) } \\
\text { receptor antagonist }\end{array}$ & $\begin{array}{l}\text { Onset: } 30 \text { seconds } \\
\text { Vd: } 2.4 \mathrm{~L} / \mathrm{kg} \\
\text { Metabolism: } \\
\text { CYP3A4 to active } \\
\text { norketamine } \\
\text { Half-life: alpha 10- } \\
15 \text { minute, beta } 2-3 \\
\text { h } \\
\text { Elimination: Urine }\end{array}$ & $\begin{array}{l}\text { LD: } 1-3 \mathrm{mg} / \mathrm{kg} \text { every } \\
3-5 \text { minute until } \\
\text { cessation of seizure } \\
(\mathrm{max} 5 \mathrm{mg} / \mathrm{kg} \text { ) } \\
\text { Infusion rate: } 0.7-15 \\
\mathrm{mg} / \mathrm{kg} / \mathrm{hr} \\
\text { Taper: } 20 \text { percent } \\
\text { reduction every } 3 \mathrm{~h}\end{array}$ & $\begin{array}{l}\text { Hypertension, caution } \\
\text { in patients with } \\
\text { coronary artery } \\
\text { disease The use } \\
\text { cardiomyopathy } \\
\text { Hypotension } \\
\text { requiring increased } \\
\text { vasopressor support } \\
\text { Intracranial pressure } \\
\text { increases } \\
\text { Agitation, confusion, } \\
\text { and psychosis may be } \\
\text { observed even after } \\
\text { drug discontinued } \\
\text { Hypersalivation } \\
\text { Severe metabolic } \\
\text { acidosis when given } \\
\text { in combination with } \\
\text { midazolam }\end{array}$ & $\begin{array}{l}\text { Should be used in combination } \\
\text { with another anesthetic, } \\
\text { particularly one with GABA } \\
\text { activity, most commonly with } \\
\text { midazolam } \\
\text { Consider as add-on therapy when } \\
\text { RSE fail to respond to other } \\
\text { third-line agents } \\
\text { May consider in early RSE as it } \\
\text { has been shown to avoid } \\
\text { endotracheal intubation }\end{array}$ \\
\hline
\end{tabular}

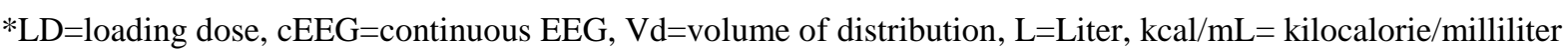

